\title{
Truffle cultivation in the south of France: technical progress and prospects
}

\section{Cultivo de trufas en el Sur de Francia: progresos y perspectivas técnicas}

\author{
Pierre Sourzat \\ Truffle Expert, Bel Air, 46240, Ussel, France
}

Pierre Sourzat, e-mail: pierre.sourzat@orange.fr

\begin{abstract}
Background: It was easier to produce the black truffle Tuber melanosporum at the end of the nineteenth and early twentieth century than nowadays. The reasons for its abundance in this period were open landscapes with an abundant rural population. The $1^{\text {st }}$ World War dramatically influenced the decline of the production of truffles. It was in the early 1970 s that truffle cultivation took off.

Objective: To review the main methods which have been used historically in the cultivation of black truffle.

Results and conclusion: The invention of the mycorrhized plant disseminated since 1973 and the numerous researches and experiments undertaken since then have made possible to maintain a truffle production which goes up considerably. Different models of truffle cultivation have been experimented from the invention of the mycorrhizal plants. Four main factors are involved in the truffle production: 1) a well mycorrhized plant, 2) a calcareous, aerated, draining soil with good biological activity, 3) a temperate climate, and 4) appropriate cultivation techniques. The truffle models are used to compare these technical aspects. The persistence of question marks in truffle cultivation justifies the continuity of the study of the characteristics of the truffle plantations in their cultural dynamics.
\end{abstract}

Keywords: Tuber melanosporum, Tuber brumale, mycorrhizal plants, fungal contaminations, truffle traps.

\section{RESUMEN}

Antecedentes: Fue más fácil producir la trufa negra Tuber melanosporum a fines del siglo xix y principios del xx que hoy en día. Las razones de su abundancia en este período fueron los paisajes abiertos con una población rural abundante. La Primera Guerra Mundial influyó conspicuamente en el declive de la producción de trufas. Fue a principios de la década de 1970 cuando se inició el cultivo de la trufa.

Objetivo: Revisar los principales métodos utilizados históricamente en el cultivo de la trufa negra.

Resultados y conclusión: La invención de las plantas micorrizadas diseminada desde 1973 y las numerosas investigaciones y experimentos realizados desde entonces han permitido mantener producciones de trufas las cuales han aumentado considerablemente. Se han experimentado diferentes modelos de cultivo de trufas a partir de la invención de las plantas micorrizadas. Cuatro factores principales están involucrados en la producción de trufa: 1) una planta bien micorrizada, 2) un suelo calcáreo, aireado y drenaje con buena actividad biológica, 3) un clima templado, y 4) técnicas de cultivo apropiadas. Los modelos de cultivo de trufas se han utilizado para comparar estos aspectos técnicos. La persistencia de limitaciones en el cultivo de las trufas justifica la continuidad del estudio de las características de las plantaciones de trufas en su dinámica de cultivo.

Palabras clave: Tuber melanosporum, Tuber brumale, plantas micorrizadas, contaminaciones fúngicas, trampas para trufas. 


\section{INTRODUCTION}

The purpose of this article is to present the history of truffle cultivation since this was invented at the beginning of the $19^{\mathrm{h}}$ century. The manuscript is divided in four sections. The first part presented are mainly historical facts. The second part intends to explain the different models of truffle cultivation in France and abroad. Then, the factors of truffle production are explored in a third part. Finally, a fourth part discusses how different technical choices are possible.

\section{THE INVENTION OF TRUFFLE CULTIVATION}

The cultivation of the truffle is supposed to have been invented in 1810 by Joseph Talon, a culture that has only just two centuries of existence in contrast to for example 5,000 years for wheat. The history of the truffle tells us that it experienced a period of abundance at the turn of the nineteenth and twentieth centuries. According to Chatin (1892), the black truffle harvested in France, in more than 40 departments, represented a record production of 2,000 tons. Three quarters of this production came from the departments of Vaucluse (470 tons), Alpes de Haute-Provence (380 tons), Lot (360 tons), Drôme in Provence (180 tons), and Dordogne (160 tons). The peak of production was probably at the beginning of the $20^{\text {th }}$ century in the Southwest of France. Currently, French production at best reaches a hundred tons (winter 1977-78) and, at worst, about ten tons (winter 2003-2004), with an average that can be located around 40 to 50 tons. The main producer departments are Vaucluse, Drôme, Dordogne, Gard, Lot, Var, and Alpes de HauteProvence (Sourzat, 2002)

The disappearance of famines at the beginning of the nineteenth century has created the conditions of overcrowding in the countryside in the middle of this century. Deforestation favored by the new freedoms acquired after the French Revolution, as well as the need to feed a peasant population that became very important, contributed to the forest clearing of many regions of France. These facts created conditions particularly favorable to the black truffle, a fungus of open environment (Sourzat, 2004). The destruction by the phylloxera (Dactylosphaera vitifoliae Fitch) of the French and European vineyards, in the 1880s, added more land favorable to the truffle. For example, when the phylloxera arrived, the Lot department had nearly 80,000 ha of grapevines, compared to about 5,000 ha today. These vines occupied the limestone hillsides and plateaux. Many bankrupted winegrowers, who had often observed the formation of natural "truffières" in their vines in connection with the presence of oak trees, replanted their plots with Quercus pubescens oaks. This reconversion was crowned with success and made the fortune of many properties of the "causses" of the Lot department and Périgord region. The Figure 1 illustrates this type of landscape.

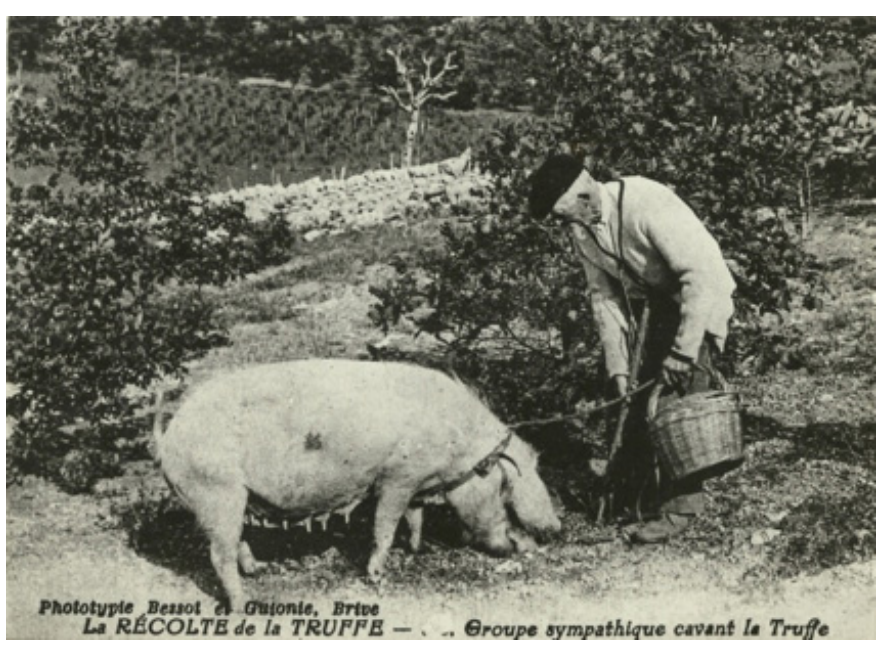

Figure 1. Truffle landscape with vines in the background at the beginning of the $19^{\text {th }}$ century.

The decline began with the First World War, during 5 years; the truffle was left unattended for food crops (Olivier et al., 2012). The rural exodus, added to the bleeding that the Great War had operated in the peasant population, created demographic conditions unfavorable to the renewal of the truffle plantations. After the Second World War, radical changes in the function of agriculture, which became productionist with industrial crops, accentuated the phenomenon of decline in truffle yields. The modes of production changed and with them the social, economic and technical behaviors. The habit of planting truffle trees was lost, in particular because production could not be guaranteed annually because of unpredictable droughts. The repayment of the annuities of the bank loans was not very compatible with the irregular financial incomes of the truffle. 
The mechanization of agricultural work applied to the truffle with the introduction of tractors and towed toothed tools in the plantations. The consequences in terms of soil compaction or damage to the roots were poorly estimated while plantations were maintained as fruit orchards (Sourzat, 2010). Pastoralism gradually disappeared in calcareous lawns and juniper moors; undergrowth was invaded by brushwood as a result of abandoning traditional practices such as collecting leaf litter or making fagots to heat the bread oven. The pruning of oaks to feed the herd of sheep at the end of the summer fell into disuse. The landscapes changed gradually creating environments that were unfavorable to the formation of natural "truffières" (Figure 2) and modified the status of dominant fungus that the black truffle had known in the early twentieth century in these areas. This set of causes resulted in a loss of potency or virulence of the truffle, a phenomenon identified and studied today, in particular at the Cahors-Le Montat Truffle Research Centre (Sourzat et al., 2014).

It is from the 1970 s that the revival of truffle cultivation was born under the impulse of pioneers such as Sylvain Floirat, Jean Rebière and Jean-Baptiste Champagnac in the Southwest; and Louis Fioc, Louis Signoret and René Gleyze in the Southeast. The mycorrhizal plant, marketed since 1973, should have favored a new start of production (Olivier et al., 2012). However, these results have not lived up to expectations. Why? Many researchers have tried to answer the reasons for the deficit in truffle production despite the fact that around 300,000 mycorrhizal trees certified by CTIFL (French Interprofessional Centre for Fruits and Vegetables) and INRA (French National Institute for Agricultural Research) were planted annually for more than 20 years, or about one thousand ha were planted each year. The main researchers who have studied this topic have mainly included Jean Grente, Gérard Chevalier, Jacques Delmas, Nicole Poitou, Charles Montant and Michel Kulifaj. The three truffle cultivation experimental plans, led by Jean-Marc Olivier since 1994, have made possible to refine cultivation practices, to improve the adaptation of truffle species to environmental conditions and to study the soils and climatic conditions of truffle production. The truffle environment has been deeply analyzed from the perspective of fungal contamination pressure in mycorrhized tree plantations (Sourzat, 2010). Soils were studied by Callot (1999) and Jaillard (2013). More recently, the systruf
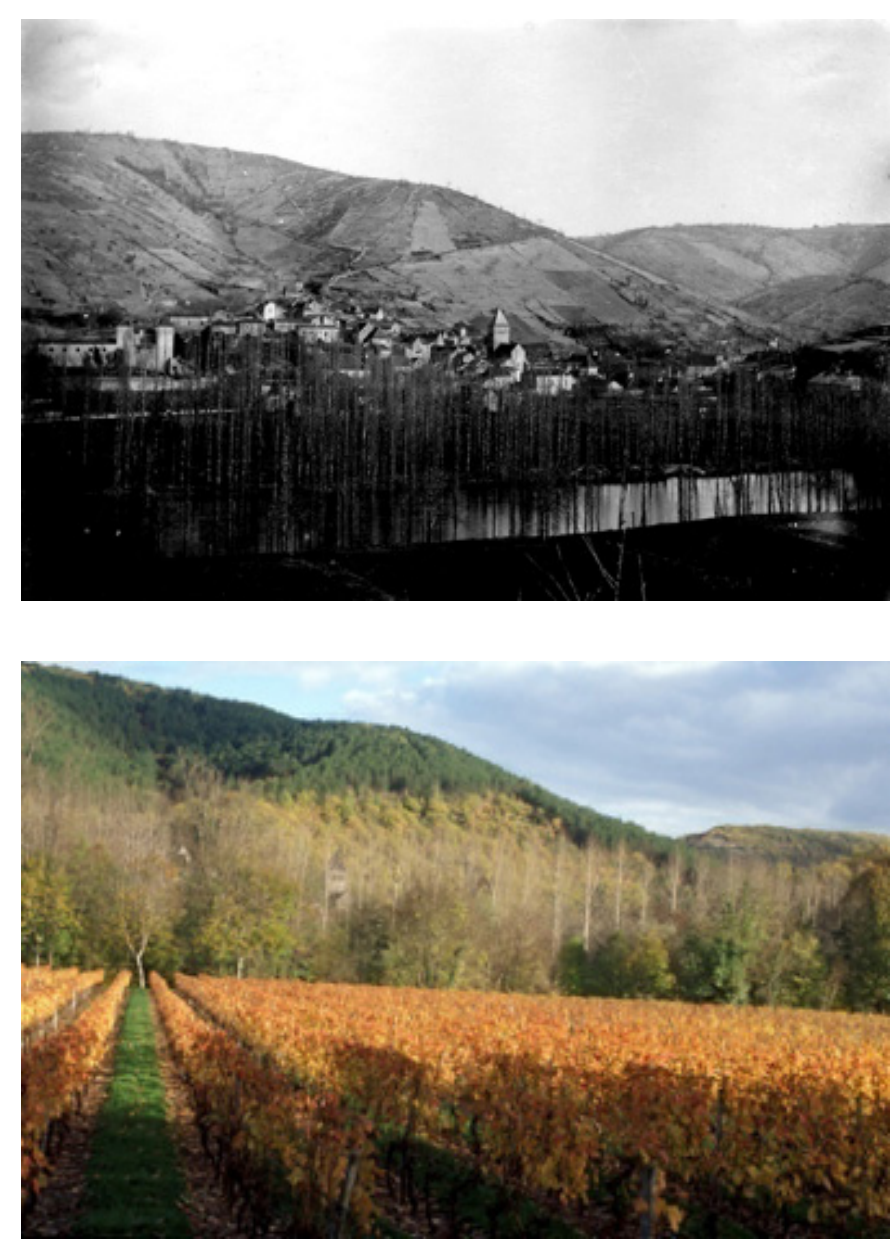

Figure 2. Hill planted with vines in 1890 (above) and bushy in 2002 (below) in Saint-Vincent Rive d'Olt in Lot, France. Truffle production developed between these two periods at the beginning of the 20th century.

program led by Selosse et al. (2014) definitely stressed the pioneering character of Tuber melanosporum, clarified the sexuality of the truffle, and demonstrated its carbohydrate nutrition via the host tree. François Le Tacon (2013) and Murat (2010, 2017) popularized with their collaborators the results of sysTRUF in the TRUFFICUlTEUR, a French truffle cultivation magazine published quarterly.

\section{MODELS OF TRUFFLE CULTIVATION}

Joseph Talon, in Croagnes, near Saint-Saturnin-les-Apt (France), is well known as an inventor of traditional truffle cultivation. Chatin (1892) retains the date of 1810 as a historical landmark in his book "The truffle". This truffle cultiva- 
tion, before the invention of the mycorrhizal plant, consisted in an indirect cultivation by sowing acorns in an environment identified as favorable and certainly very rich in spores of Tuber melanosporum.

\section{THE TRADITIONAL MODEL}

The traditional truffle model has dominated the period of abundance of truffle production in the late nineteenth and mid-twentieth centuries, with persistence here and there, until very recently in some regions, where truffle cultivation has strongly influenced the countryside and its sociology. The plantations were made from Quercus pubescens oaks (SouthWest), Quercus ilex and Quercus robur oaks (South-East) planted or sown. Cultivation practices consisted mainly of manual tillage of the best burnt areas or "brûlés" (which evolved towards mechanical work with the appearance of tractors), the pruning of trees and sometimes covering the best "brûlés" with branches. The lack of quality control of inoculated trees and the use of varying methods according to local or family tradition, have often been mentioned to explain the random results of the second half of the $20^{\text {th }}$ century. In fact, this model has perpetuated simple cultivation methods which have produced excellent results until the decline of truffle production whose causes are still the subject of conjecture.

\section{THE PALLIER MODEL}

Truffle arboriculture or the "Pallier" model (Sourzat, 2002) is the model that has been popularized since the rebirth of truffle cultivation in the 1970s when recovery efforts were undertaken at all levels by people of the truffle world and society. It is a rational model which consists in cultivating mycorrhized truffle trees according to the concepts of arboriculture (tree planting, tillage, irrigation, pruning, fertilization amendment and phytosanitary treatments) (Figure 3). It has produced economically satisfactory results for a number of years at its inception in the Périgord. It is summarized in the following points: plantation of mycorrhized trees on favorable soil (limestone), controlled irrigation of truffle trees, careful and adapted tillage and vigorous pruning to keep the environment open.

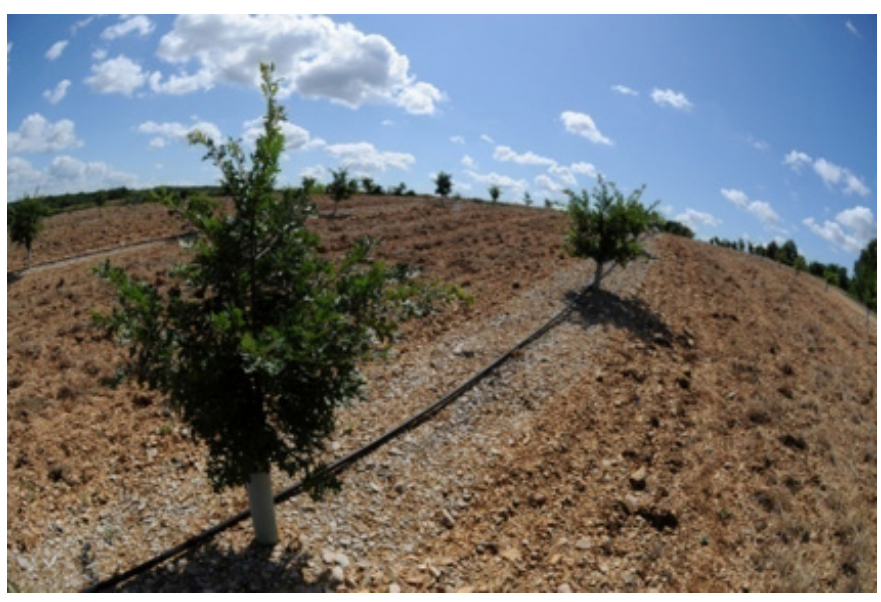

Figure 3. Plantation as truffle arboriculture illustrating the "Pallier" model.

This model allowed to collect truffles early but is penalized by the production of truffles Tuber brumale (especially with hazel) in proportions that often drastically reduce the technical and economic results. However, although these disadvantages have been frequently pointed out, it seems that they were related to an environment where the pressure of contamination of other fungi was very high. The truffle growers on the Sarrion plateau (Aragon, Spain) are convinced that this truffle cultivation model is adapted to their environment.

\section{THE TANGUY MODEL}

The truffle cultivation in calcareous lawn or "Tanguy" model (Figure 4) was defined after two rainy summers, 1992 and 1993 (Sourzat, 1995), followed by two exceptional harvests in the Tarn-et-Garonne (at the plantation of the initiator of this model), the Périgord (two producers), the Lot department (one producer) at Miers, Bouat and Meynard, respectively, and the Vaucluse (one producer in Pina, Apt). Other truffle growers then reinforced the perception of this model of truffle cultivation with their plantations following a similar technical itinerary. The peculiarity of this model is the planting of mycorrhized trees followed by a natural recolonization of the environment by herbaceous vegetation. In the plantations used to define this model, tillage was stopped as well as any intervention on soil two to three years after planting. It was only after the beginning of production that the truffle growers again took interest in cul- 
tivating the planted site. The first harvests took place from 10 to 12 years. In some plantations, tillage has been more or less used; in others, it was enough to mow the lawn. Among the herbaceous vegetation characteristic of these sites, grasses, particularly Bromus erectus Huds., Festuca ovina L. and Elymus repens L., are present. The ecological characteristics of these truffles close to those of the natural environment have made it possible to reformulate the "Tanguy" model as "calcareous lawn truffle cultivation" (Sourzat, 2002). This model generally offers production levels (up to $100 \mathrm{~kg} / \mathrm{ha}$ ) similar to those of the late nineteenth or early twentieth century. On the other hand, truffles are frequently on the surface, presenting a sensitivity to frost, insects and slugs. Solutions have been sought and implemented to remedy these difficulties. It should be noted that the growth of trees is retarded by grass competition: if the lawn protects against fungal contamination, it delays the beginning of truffle production. In the absence of a fungal contamination pressure, in particular by Tuber brumale, this model is not justified (Sourzat and Tabouret, 2008).

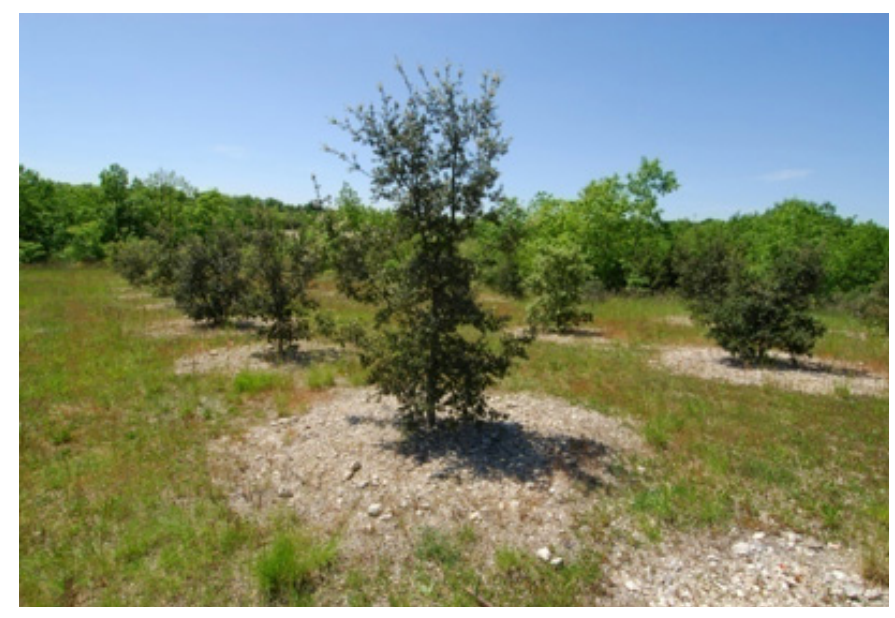

Figure 4. Calcareous lawn planting illustrating the "Tanguy" model

\section{THE THREE-STEP METHOD}

This three-step concept was first formulated in the 2002 edition of "The Practical Guide to Trufficulture" (Sourzat, 2002). Three activities were used to summarize a precautionary technical itinerary in three stages: planting, maintaining and producing.
From these three activities marking three realities, one has characterized the work to be accomplished during at least twenty to thirty years. The precautions to be taken have been emphasized by considering that the cultivation of truffles still requires experiments by research centers as well as by truffle growers who are confronted with their own difficulties. From this conception, three essential steps have been distinguished in the life of the truffle plantation. The steps proposed in the Practical Guide to Truffle Cultivation (Sourzat, 2002) are as follows: 1) To ensure the best possible growth of the Tuber melanosporum mycorrhizal plant in the first year of planting; 2) To install the natural environment (the living community: flora, fauna, fungi) required by the truffle before production by not seeking to accelerate the growth of mycorrhizal trees; and 3) To harvest with the aim of improving production in quantity and quality while preserving its durability. During the second stage, it is necessary: a) to establish an ecosystem naturally contributing to the production of Tuber melanosporum; and b) to avoid fungal contamination of roots by opportunistic contaminating mycorrhizal fungi different than those of truffles.

\section{THE JAAD METHOD}

In the edition of the "New Manual of Trufficulture in 2007" (reissue of Dr. Pradel's manual of 1914), the JAAD method was formulated. The inventor of this method wrote on page 195: "Formula J.A.AD. A new cultural itinerary combining the slogan: planting, cultivating, harvesting" (Dessolas et al., 2007). The JAAD method, which distinguishes the three stages of the plantation: "Young” ('Jeune' in French), "Adolescent”, and "Adult", is similar to those described in "The Practical Guide to Truffle Cultivation" (Sourzat, 2002), but evolved in the "Dare to cultivate truffle in another way" in 2011. It introduces the planting of the ridge in the "young" phase and then the enlargement of this ridge over the years by mechanically bringing (by means of a remote disk tool) soil to the line of trees as to transform this ridge into a platform. In addition, regeneration of the root system is on the agenda. Gérard Chevalier pointed out on page 54 of his Guide the end of the "sacred dogma" of surface soil work, to avoid damage of the root system. He adds that "for the first time, a method recommends a deep work from the first year of vegetation. It is a real revolution". Gérard Chevalier, formulated in 
2010, the rational method of trufficulture (MRT). He was also at the origin of the concept of perma-cultivation, presented at the IW trufficulture: a new chance for the cultivation of truffles”. He had already presented the method at the $6^{\text {th }}$ conference of the TAUESG group in Norwich (UK) $\left(6^{\text {th }}\right.$ TAUeSG Conference 26-28, August 2015). At this stage, there are no known results of these two methods because they were recently formulated.

\section{THE ANGELLOZZI METHOD}

During the Congress of Spoleto in 2008, the Angellozzi method was explained by Pierre Sourzat and Gian-Luigi Gregori. With the truffle cultivation of the family Angellozzi (Roccafluvione, Ascoli Piceno), it is a matter of managing the growth of the host tree in its aerial and underground parts in deep soil. This management consists of: 1) maintaining the root system of the tree at a juvenile stage; and 2) promoting a perennial truffle production with the appearance and growth of a large number of fruiting bodies. The Angellozzi method is characterized by two stages: 1) planting perfectly mycorrhized (certified) trees under apparently very suitable environmental conditions with limited maintenance to manual tillage and pruning; and 2) manually and deeply soil tillage, frequently watering in small amounts and control of the tree growing by a vigorous pruning. The Angellozzi method has enriched the conceptions of French and Italian truffle cultivation, notably from the viewpoint of controlling the growth of the host tree in relation to the sustainability of the truffle production (Figure 5).

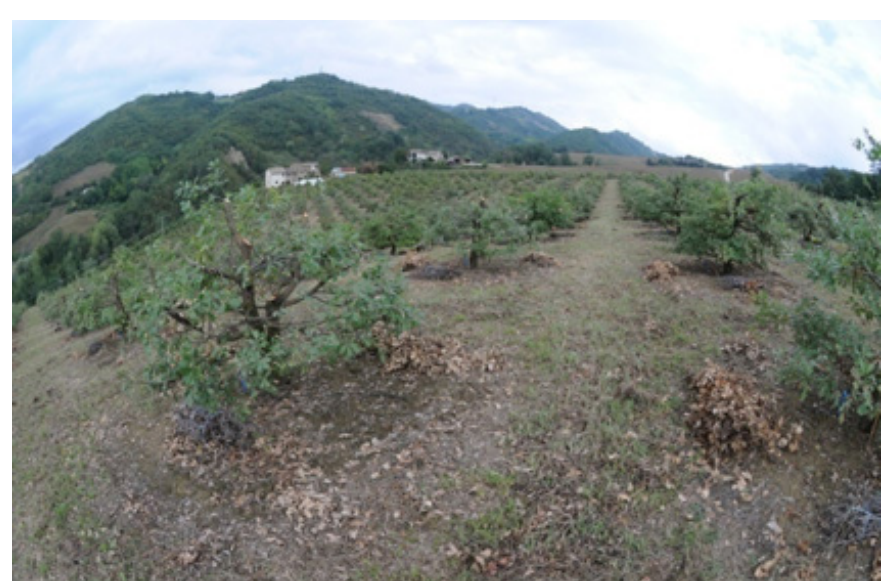

Figure 5. Angellozzi plantation heavily pruned in Italy.

\section{THE MAIN FACTORS OF TRUFFLE PRODUCTION}

The main factors of truffle production might be summarized in 4 points: 1) a mycorrhized tree; 2) a calcareous, aerated, draining soil with good biological activity; 3) a temperate climate; and 4) appropriate cultivation techniques. Truffle plants produced by specialized nurserymen, controlled by INRA and CTIFL, and marketed in France, have an excellent level of mycorrhization by Tuber melanosporum or other targeted truffle species. The controversy of the 1970 s and 1980 s concerning the usefulness of using these plants is no longer necessary.

Classical soil analysis is an essential tool in the knowledge of these soils which is generally complemented by an in-depth examination of the soil profile, carried out from a soil pit. Limestone formations from different geological eras are at the origin of the truffle soils encountered in France. Among these formations, limestones of the Secondary era hold an important place, especially those of the Jurassic and Cretaceous periods. On the tertiary (Oligocene, Eocene) and quaternary alluvium, there are also excellent truffle soils. Truffle soils are classified mainly into three soil types: Rendzines, calcareous brown soils, and calcic brown soils. Dolomitic soils are more rarely found. According to the new classification of the "Référentiel pédologique" (Soil repository, French Association for the Study of Soil, 2008), the Rendzines are called rendosols (rendisols for calcic soils) (Figure 6).

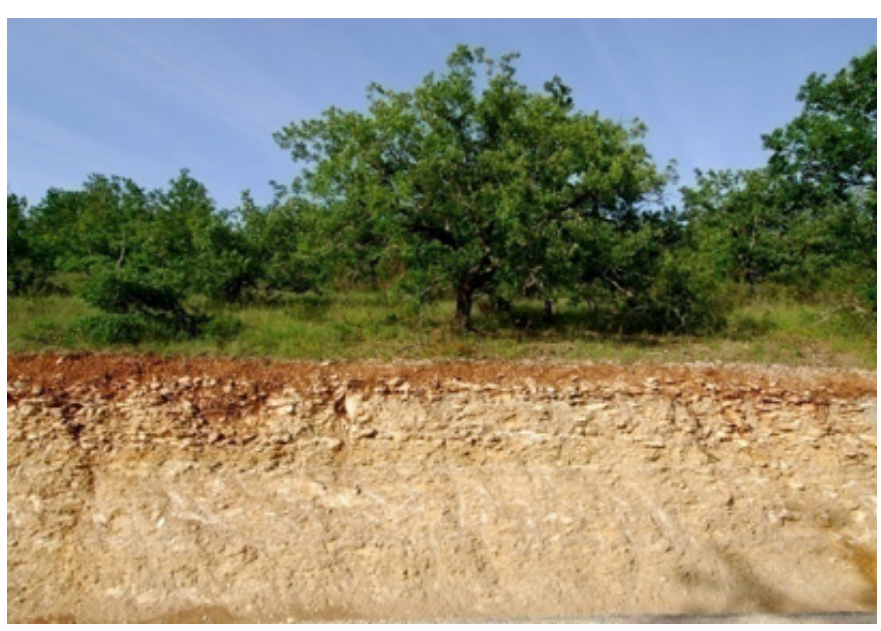

Figure 6. Geological section on a Rendosol or Jurassic limestone with shallow truffle soil in the first $20 \mathrm{~cm}$. 
The calcareous brown soils are found in calcosols and calcic brown soils in calcisols. Other soil types are also trufflecompatible: lithosols and colluviosols, characteristic of natural "truffières" without possibility of real culture with modern equipment, as well as certain fluviosols especially along the Rhone valley.

Climate is also a determining factor in truffle production, which includes the distribution of rainfall and the variation of temperatures during the truffle cycle. The climatic requirements of the truffle Tuber melanosporum can be summarized with the following 4 points: i) Relatively wet and warm spring without late frost, so as to favor the re-growth of the mycelium and the birth of truffles; ii) Warm summer, interspersed with rainstorms that ensure the good evolution of the truffle; iii) Autumn normally wet and without early frost destructive of truffles; and iv) Winter without severe frosts ongoing for several days, which can destroy truffles, and moderate rainfall so as to ensure a harvest under correct soil conditions.

The altitude of truffle fields in the south-west of France is generally between 100 and 400 meters. In the south-east, the Mediterranean climate allows the installation of truffle trees above this altitude. In the Hautes-Alpes department, natural truffle trees are present up to $1,500 \mathrm{~m}$ a.s.l. in sun-exposed sites (at the lower limit of the larch stage), while on the plateau of Larzac (department of Aveyron), there are natural "truffières" at $800 \mathrm{~m}$. a.s.l. under good sunshine conditions.

The perception of the environment complements those of soils and climate at the scale of a region. It provides a synthetic view of the types of vegetation that provide information on both soil and climate. For example, the presence of chestnut or heather ash in a plot allows considering that it presents an acidic soil inappropriate to the black truffle. However, advances in science and field observations have recently expanded the scope of these techniques to the "truffle traps" and control of "the pressure of fungal contamination". The concept of truffle traps, consisting of bringing spores into holes made in burn areas ("brûlés"), arose from the understanding of the sexual types of the truffle (Murat et al., 2017) and the necessity to reinforce the truffle inoculum through spore enrichment. Spore enrichment bring the two sexual types at the same point and can, in theory, increase the probability of mating events, thus promoting the fruiting of the ascomata. The fungal contamination pressure is exerted by the old plantations, or hedges, of oaks at the border of the young plantations (Figure 7).

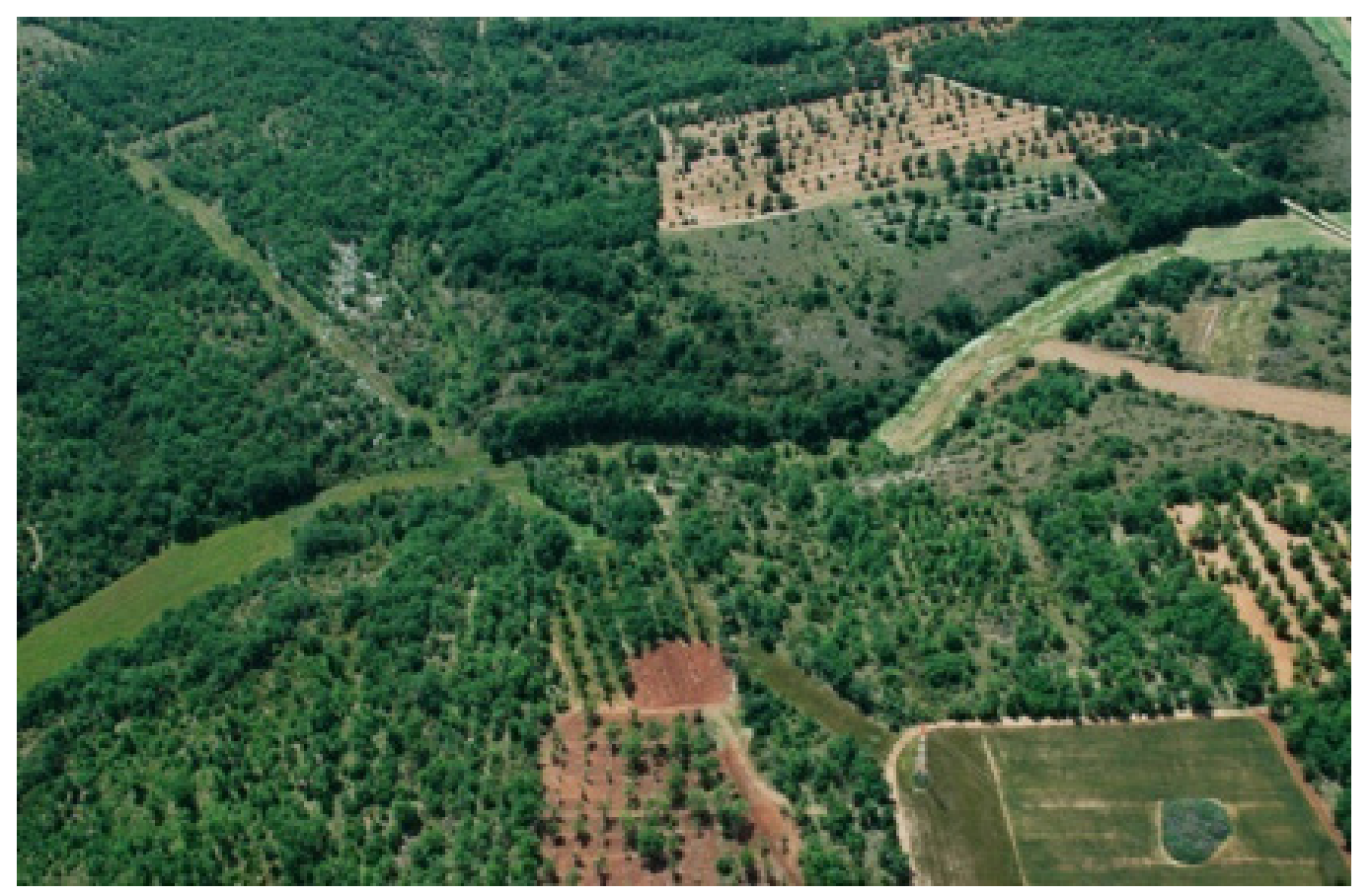

Figure 7. Aerial view of the Lalbenque region in Lot, France where the young truffle plantations are surrounded by old plantations exerting a strong pressure of fungal contamination. 
The roots of these oaks carry mycorrhizae formed by forest fungi, which can displace Tuber melanosporum mycorrhizae of the young trees planted. Controlling the contamination pressure consists in favoring "truffle bastions" with large plots whose edges will be protected from fungal contamination. The sanitary zone will be created either by making trenches along the edge of the old woods (passage of chisel), or by leaving at least 8 to $10 \mathrm{~m}$ between the first lines of mycorhized trees and the first old oaks (Sourzat, 2010).

\section{THE APPROPRIATION OF THE TECHNICAL FRAMEWORIK BY THE TRUFFLE GROWERS}

Once the truffle models have been presented and the main factors of truffle cultivation identified, it becomes possible to formulate many other types of truffle cultivation. In reality, if interesting results are found on a plantation or several plantations on a site or in a region, or even in another country or on another continent, it may be considered that this is the correct method of producing truffles for these particular areas. Crossing good and bad results observed in similar or very different environments over the decades has shown, not the perfect method, but the factors that determine the results of production. For example, truffle arboriculture or "Pallier" method, which has shown its limits in France in traditional truffle areas, today presents very convincing results in the large cereal and wine plains of France. In Australia, regular use of systemic herbicides in plantations has no negative impact on the results in terms of yield and organoleptic quality of truffles (Sourzat, 2012).

\section{GRASS COVER CREATES BIODIVERSITY CONDITIONS}

This simple logical analysis shows that it becomes possible to develop a technical framework by considering a certain number of characteristics of the stages of the life of a truffle plantation. In the context of the studies carried out, five stages are distinguished: timing of planting, maintenance before fruiting, cropping during harvesting, renovation or regeneration and grubbing-up. At the beginning of step 1, a diagnosis must be made of the soil's potential, the availability of water for irrigation, and the presence of woods around the plantations. These elements will determine soil improvements (mainly subsoiling, grinding and liming), choice of species, planting density, orientation of tree lines, and distance between outer lines and edge woodlands. Step 2 is the most debated one and the most decisive. It is very variable from the point of view of soil maintenance if one considers the methods presented previously. Grass cover creates ground-level biodiversity conditions close to those of natural truffle "truffière" (Figure 8). On the other hand, it can penalize the growth of the host trees and limit, in some cases, the installation of the truffle mycorrhizal root system in the superficial horizon. Step 3 does not seem to vary much between the different models of truffle cultivation used in France and abroad. It consists of maintaining the soil aerated, controlling the water requirements of the truffle, and limiting the canopy closure by cutting or pruning trees. Stage 4 aims to restore the conquering space of the truffle by removing trees for re-creating the pioneer system favorable to Tuber melanosporum (Sourzat et al., 2008). Step 5 closes the production cycle with the removal of trees.

\section{CLAIMING ITS OWN MODEL OF TRUFFLE GROWING}

With nearly 40 years of experience since the appearance of the controlled mycorrhizal plant in 1973 , one can write that it is desirable to construct and claim its own model of truffle cultivation at a given site. Identification and control of interacting factors is the key to success towards sustainable truffle production. The typology of truffle cultivation methods has been as beneficial as experimentation in advancing the perception of the most relevant factors. By comparing many plantations managed under different models, we can identify a certain number of constant or regular factors that seem to determine the outcome of cultivation.

While there is a wealth of knowledge for pre-planting diagnostics and specialist advice that can often be trusted, everything is not fully adjusted for a production with so many parameters involved. A small share of risk remains that can lead to the lack of success. As far as truffle ecosystem is concerned, there are shady areas which still have not been fully understood in order to understand why soils which were once capable of producing truffles in abundance have lost this ability despite the use of controlled mycorrhizal plants. The work carried out over the 


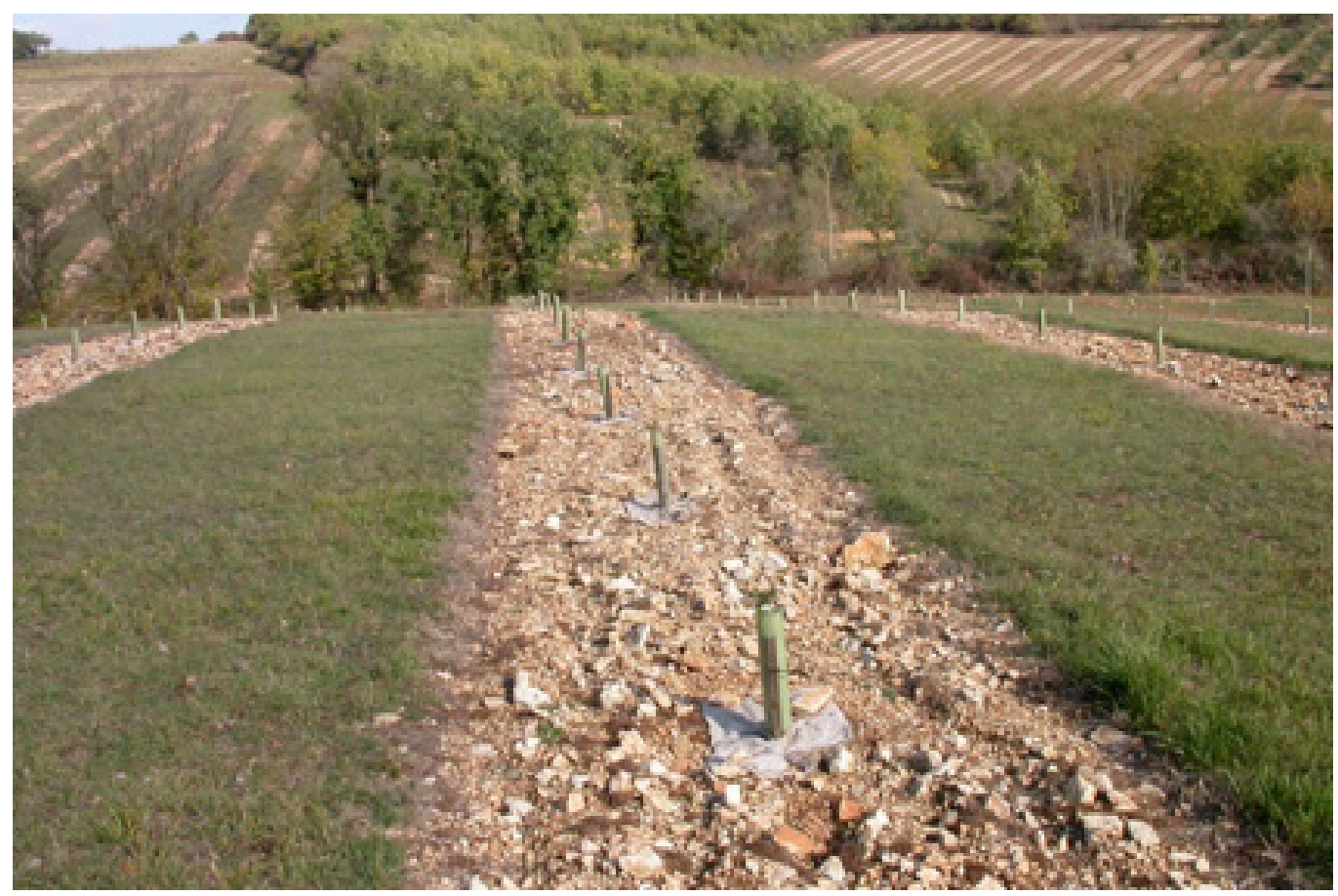

Figure 8. Truffle plantation with grass between the rows in order to favor biodiversity.

last few years emphasizes that failures are observed in the absence of virulence of Tuber melanosporum, which is generally accompanied by: 1) the production of Tuber brumale instead of Tuber melanosporum, 2) less resistance of the truffle to the drought, 3) a lack of sustainability of truffle production, and 4) a late induction of production or even an inertia in this way (Sourzat et al., 2014). The persistence of pitfalls in truffle cultivation justifies pursuing the study of the characteristics of truffle plantations in their cultural dynamics or technical itinerary. The mistake would be to think the discovery of "a good method" or "the right method" when one believes to know all characteristics of the plantation that produces exceptional results. Pitfalls or failures are mostly observed in areas where the forests around the truffle plantations are a source of inoculum of competing mycorrhizal species. When a truffle tree does not produce, the analysis of its root system most often reveals that it is no longer mycorrhized by the truffle species which was initially inoculated in a nursery.

\section{CONCLUSIONS AND PERSPECTIVES}

The research carried out for more than 40 years has not yet yielded all the hoped-for results to restore the truffle production levels of the late nineteenth century in France, which were far superior to those of the present day. This is partly due to smaller areas dedicated to truffle growing. However, production factors are better known through the work of scientists, experiments and the different truffle cultivation models introduced by truffle growers since the extension of the controlled mycorrhizal plant from 1973. Since this important stage, the conditions which, in a natural or cultivated environment, allow defining a standard model of truffle cultivation should be always analyzed. From these observations supplemented by production results, it became clear that the ideal cultural route can only result from an adaptation of the technical choices to current conditions of the agricultural and rural environment of a specific area. The present conditions in France are different from those of the era of abundance of the black truffle.

The international reputation of the truffle, as a high-end product of gastronomy, has helped to bring Tuber melanosporum out of its natural area (e.gr. France, Spain and Italy). Other species followed as Tuber aestivum syn. uncinatum and Tuber borchii. The cultivation of T. melanosporum was introduced both in the northern hemisphere and in the southern hemisphere, where vines had already been introduced for decades. 
The successes obtained outside Europe, particularly in Australia, are an encouragement to persevere. The production of black truffle has become a high value crop that is of interest to many agricultural investors.

In southern France, much progress remains to be done to improve T. melanosporum cultivation. Currently, France suffers from climate change marked by recurrent droughts and longer episodes of heat waves. Agricultural decline (fewer farmers, more afforestation and more pressure of fungal contamination) is also penalizing the truffle cultivation. Irrigation becomes necessary despite a tradition of cultivation without water supply. In fact, thunderstorms in the summer were sufficient in the past to meet the water requirement of the fungus. Farther south, the Spanish truffle growers on the Sarrion plateau are demonstrating that truffle arboriculture with annual tillage and consistent water inputs produced economically very attractive yields in an open environment (Perales, 2017). With plantations over large areas, several dozen hectares, they create truffle bastions where T. melanosporum introduced with mycorrhized plants dominates species likely to exert fungal competition.

The French federation of truffle growers has indicated through its President that it is the agricultural world that holds the key to the development of truffle cultivation because farmers own the majority of land and have the means to manage it (Tournayre, 2017). However, non-farmers are often non-peer experimenters opening new paths for truffle cultivation. The afforestation of oaks around the plantations must be taken into account in the management of the plantations. Arrangements are made by truffle growers for the truffle T. melanosporum to withstand the pressure of competing fungal species, such as the truffle T. brumale.

\section{ACIKNOWLEDGMENTS}

The author acknowledges to Dr. Alexis Guerin-Laguette from Plant and Food Research Institute, Christchurch from New
Zealand and Prof. Jesús Pérez Moreno from Colegio de Postgraduados, Mexico for their invitation and encouragement to write this article.

\section{REFERENCES}

Association française pour l'étude du sol, 2008, Référentiel pédologique, Editions Quae, Montpellier.

Callot, G., P. Byé, M. Raymond, D. Fernández, J.C. Pargney, A. Parguey-Leduc, M.C. Javex-Fabre, R. Moussa, L., 1999. La truffe, la terre, la vie, Editions INRA, Paris.

Chatin, A., 1892. La Truffe. Baillère, Paris.

Dessolas, H., G. Chevalier, J.C Pargney, 2007. Nouveau manuel de trufficulture, Editions Mises en pages, Paris.

Jaillard, B., D. Barry-Etienne, C. Colinas, A.M. De Miguel, L. Génola, A. Libre, P. Neuveu, D. Oliach, W. Saenz, M. Saez, X. Salducci, G. Souche, P. Sourzat, M. Villeneuve, 2013. Alcalinité et structure des sols déterminent la production truffière en régions pyrénéennes, Le Trufficulteur Français 85. Fédération Nationale des Producteurs de Truffes, Paris.

Le Tacon, F., B. Zeller, C. Plain, C. Hossann, C. Brechet, C. Robin, 2014. Le mode d'acquisition du carbone pendant le développement des ascocarpes de Tuber melanosporum Vittad., Le Trufficulteur Français 83. Fédération Nationale des Producteurs de Truffes, Paris.

Murat, C., F. Le Tacon, J.M. Olivier, M.A. Selosse, 2010. Bilan des premières expériences du projet Systruf. Le Trufficulteur Français $72: 7-8$.

Murat, C., M.A. Selosse, E. Taschen, L. Schneider-Maunoury, F. Richard, F. Martin, F. Le Tacon, 2017. Quelques considérations sur le réensemencement par ascospores des truffières à Tuber melanosporum. Le Trufficulteur $98: 12-13$.

Olivier, J.M., J.C. Savignac, P. Sourzat, 2012. Truffe et Trufficulture, Editions fanlac, Périgueux.

Selosse, M.A., E. Taschen, M. Sauve, F. Richard, 2014. La truffe, une domestication en route ? Le Trufficulteur 88: 18.

Sourzat, P., 2002. Guide pratique de trufficulture. Station d'expérimentation sur la truffe, Lycée Professionnel Agricole, Le Montat.

Sourzat, P., 2004. Questions d'écologie appliquées à la trufficulture. Station d'expérimentation sur la truffe, Lycée Professionnel Agricole, Le Montat.

Sourzat, P., 2008. Le principe de précaution en trufficulture. Station d'expérimentation sur la truffe, Lycée professionnel Agricole de Cahors, Le Montat.

Sourzat, P., 2010. L'Environnement truffier: contraintes et gestion. Station d'expérimentation sur la truffe, Lycée professionnel Agricole de Cahors, Le Montat.

Sourzat, P., P. Tabouret, 2008. La truffe Tuber brumale. Fédération Française des Trufficulteurs, Paris.

Sourzat, P., D. Bouyssières, J.M. Dubiau, A. Sanchez, F. Chaumeil, L. Genola, W. Saenz, 2014. Compte rendus des actions d'expérimentation sur la truffe (selon le programme validé par l'Oniflhor et la Région Midi-Pyrénées). Station d'expérimentation sur la truffe, Lycée Professionnel Agricole, Le Montat. 